\title{
Water Quality and Environmental Impact Assessment of a Tropical Waterfall System
}

\author{
Benedict O Offem (Corresponding author) \\ Department of Fisheries, Faculty of Agriculture and Forestry \\ Obubra campus, Cross River University of Technology, Nigeria \\ Tel: 08-055-930-219 E-mail: benbeff06@yahoo.com \\ Gabriel U Ikpi \\ Department of Fisheries, Faculty of Agriculture and Forestry \\ Obubra campus, Cross River University of Technology, Nigeria \\ E-mail: gikpi@yahoo.com
}

\author{
Received: September 25, 2011 \\ Accepted: November 10, $2011 \quad$ Published: December 1, 2011 \\ doi:10.5539/enrr.v1n1p63 \\ URL: http://dx.doi.org/10.5539/enrr.v1n1p63
}

\begin{abstract}
To provide information on the water quality and productivity of waterfalls, monthly samples were taken from three sites along the $6817.7 \mathrm{~m}$ long Agbokum waterfalls for 24 months (January 2007-January 2009) during wet and dry seasons. Apart from pH, Cadmium (Cd), Chromium (Cr) Ammonium (NH4+), Lead ( $\mathrm{Pb}$ ), alkalinity, Surface Temperature, Air temperature, water velocity and rainfall, all other environmental parameters showed significant variation between sampling sites. Most parameters including water discharge (1496.5 \pm 82.9 ), dissolved oxygen $(9.6 \pm 0.2)$, conductivity $(69.0 \pm 18.5)$, calcium $(16.9 \pm 1.2)$, magnesium $(2.5 \pm 0.04)$, silicon $(2.5 \pm 0.04)$, Iron $(0.08 \pm 0.02)$, Manganese $(0.8 \pm 0.2)$, Total solids $(178.6 \pm 8.8)$ and Total hardness $(74.5 \pm 4.3)$ were highest in waterfalls region (midstream) of the river. Deleterious levels of $\mathrm{Fe}, \mathrm{Pb}, \mathrm{Cd}$ and $\mathrm{Mn}$, above recommended levels, in the waterfalls region of the river and in the wet samples coupled with the acidic nature of the wet samples poses potential health hazards to the aquatic organisms and the inhabitants of the area that use this water resource directly for domestic purpose without treatment. The results indicate a deteriorating water quality of Agbokum waterfalls with the waterfalls region and wet season being most critical in the effective management of the water body.
\end{abstract}

Keywords: Waterfalls, Hydrological parameters, Physic-chemical properties, Heavy metals, Wet season, Dry season, Seasonal variation, Spatial variation

\section{Introduction}

Water resource is one of the major components of environmental resources threatened by exploitation and pollution due to human activity (Efe, 2002a). In the developing countries, good quality water is scarce because of environmental pollution and degradation (Efe, 2002b). Regular monitoring of water resources in the area is therefore important for proper management strategies. Waterfalls, most of which are formed from stream or river which cascade from a high elevation over a cliff or rock, had very little attention from researchers the world over. In Africa, the reason being that, waterfalls were named after deities and were used as places of traditional and ancestral worships. In other places, the intensity of waterfalls and pressure generated from it due to gravity has given the impression of a lifeless zone (Chernicoff et al., 1997). Knowledge of waterfalls systems in Africa are therefore limited to hydrology and geological features (Fischer and Harris, 2003; Chester et al., 1999) and as natural monuments for revenue generation because of their ecotourism potentials (Ayodele, 1988; Krinitskii, 1972).

Physico-chemical characteristics are very vital water quality monitoring parameters due to their instability once water is extracted from its source. Knowledge of physico-chemical parameters provides information on the productivity of water resource, type of water treatment process to be adopted and permit better understanding of the ability of populations of organisms to survive in them (Boyd \& Lichtkopeller, 1985; Ayodele \& Ajani, 1999; 
Adebisi, 1981). Different causal influences which determine the quality of water show a characteristic change from season to season (Islam et al., 1974; Chowdhurry \& Mazumder, 1981; Nasar et al., 1991).

Water quality researchers had restricted their work on rivers, stream and Ocean (Etim \& Akpan, 1997; Akpan \& Offem, 1993; Ama-Abasi et al., 2004; Rahim et al., 2002; Chapman, 1996; Daddy \& Falaye, 2004; Balogun \& Aduku, 2004; Mbagwu, 1991). However, little or no work had been carried out on parameters of the waterfall ecosystem. This paper, therefore, investigated the dynamics of physical and chemical parameters of a waterfall in south eastern Nigeria at spatial and temporal scales.

\section{Materials and Methods}

\subsection{Study area}

The study area is Agbokim Waterfalls in Cross River State, Nigeria, latitude $5^{0} 59^{\prime}$ North and longitude $8^{0} 45^{\prime}$ East. It is bounded in the West by the Cross River and in the North by the Cameroon high forests. The climate is the tropical hinter-land type, with wet (May-November) and dry (December-April) seasons. Mean annual temperature ranged between $20^{\circ} \mathrm{C}$ and $32^{\circ} \mathrm{C}$ and annual total average rainfall, from $1450 \mathrm{~mm}$ to $3015 \mathrm{~mm}$. The vegetation is the rainforest type with Soil consisting of deep laterite and dark fertile, clayey and loamy soils. The Waterfalls is drained by two small rivers, Ekue and Bakue, which are tributaries of the Cross River system. Of ecological importance are numerous small pools and swamps which are found along the length of the waterfalls. The high annual discharge and rainfall of the area provide excellent buffers against natural ecological stresses such as drought (Teugels et al., 1992). For the purpose of this study, the $6817.7 \mathrm{~m}$ long waterfall is divided into three reaches; upstream, midstream (region of water fall) and downstream. Upstream is $2003.13 \mathrm{~m}$ long with substrate of gravel and rocks under fast water current and shoreline covered with high forest and cocoa farms, Midstream length of $807.42 \mathrm{~m}$ has substrates of sand and rocks under heavy water turbulence with shoreline sparsely shaded with vegetation while downstream length, $2003.13 \mathrm{~m}$ has fine sand and clay under slow water current with an extensive wide area.

\subsection{Hydrological parameters}

Three sampling sites were selected along the length of the water falls, with one site randomly occurring in each of the three reaches. Monthly hydrological and physico-chemical parameters were taken for 24 months (January 2007-January 2009), in all sampling stations during wet and dry seasons.

Rainfall data for the study area were obtained from weather meteorological station located at the sampling site. Water level was determined with a lead sinker attached to a calibrated rope. The sinker was lowered down into water until it reached the substrate. The depth was then read from the calibrated rope. The procedure was repeated in two other locations randomly selected from the edge and middle of water within the sampling site. In smaller sites water level was determined by a rope marked at $2.5 \mathrm{~m}$ interval and strung across the river. A measuring pole was used at every marker to determine the depth at that point. For larger sites a Lowrance depth sounder was used to take reading every 5 seconds while crossing the river at a steady speed. River width was measured with a long calibrated rope in three places in each sampling sites and the average was taken. Water velocity (flow velocity) was determined to $0.03 \mathrm{~m} / \mathrm{sec}$ accuracy with Wagtech current flow meter, model WFM001 with $125 \mathrm{~mm}$ diameter impella. Water discharge was determined as in Fischer and Harris (2003) using the formula: WTD $=$ CSA x WD x WV. Where WTD = Water discharge $\left(\mathrm{m}^{3} \mathrm{~s}^{-1}\right), \mathrm{CSA}=$ Cross Sectional Area $(\mathrm{m})$; WD $=$ Water dept $(\mathrm{m})$ and WV $=$ Water velocity $\left(\mathrm{ms}^{-1}\right)$.

\subsection{Physic-chemical parameters}

Temperature values were recorded from a mercury-in glass thermometer graduated in units of ${ }^{0} \mathrm{C}$ and measured to the nearest $\pm 0.1^{\circ} \mathrm{C}$ by immersing the thermometer slightly under the surface of water $(2 \mathrm{~cm})$ for 5 minutes until mercury stood at one place. Pye Unicam Model 7065 electronic metre at $250 \mathrm{C}$ measured to the nearest \pm 0.1 after standardization with buffer solution at $\mathrm{pH} 4,7$ and 9 was used for $\mathrm{pH}$. The dissolved oxygen concentration of the water samples was determined to accuracy of $\pm 0.1 \%$, with a Fischers digital oxygen analyzer. Water transparency was measured by use of Secchi disc (Golterman, 1969). The disc was lowered into water and the depth at which it became invisible was recorded. It was then gradually withdrawn from the water and the depth at which it became visible was noted. The transparency of the water at that station was the mean of the two readings. For the total dissolved solids (TDS), the Hach TDS meter was put on, the reading zeroed and then the electrode dipped into the water sample and the reading taken to the nearest $\pm 1 \%$ of full scale approximately. Conductivity was assessed by putting on the Suntex conductivity meter, adjusting the reading portion and dipping the meter into the water sample and approximate reading taken to the nearest $\pm 1 \%$ of full scale. Total hardness, ammonia, free Carbon dioxide, Acidity, Chemical Oxygen Demand, was obtained by titrimetric 
method (APHA, 1998). Ammonia, Nitrate and Phosphate were measured according to "Standard Methods for the Examination of Water \& Wastewater," (APHA, 2005). Biological Oxygen Demand was determined by difference between initial and final dissolved oxygen after incubation for 5 days at room temperature of $\left(20{ }^{\circ} \mathrm{C}\right)$. Total alkalinity was measured by titrating water samples with sulphuric acid standard solution, using a drop of phenolphthalein solution and one sachet of bromcresol green-methyl red as indicator, until the sample changed from blue green to pink. Total alkalinity which is expressed in $\mathrm{mg} / \mathrm{L}$ is the total number of drops of sulphuric acid solution used multiplied by 17.1 (Fish Farmers' Water Quality Testing Kit Manual, 1990). Bicarbonate ion was measured with $\mathrm{pH}$ electrode dipped into the tip of the conical container. Sample water was passed through until a constant reading was obtained and a marble powder was added, to completely cover the electrode ball. After about 2 minutes, the $\mathrm{pH}$ was read again. The temperature of the marble was monitored with thermometer during measurement. Carbonate ions was determine by placing hydrochloric acid, between 2 and $10 \mathrm{ml}$ of water sample in a gas generator and insert tube filled with $20 \mathrm{ml}$ hydrochloric acid (10\%). After connecting to the apparatus, the graduated tube was filled by raising the level container. The gas generator was then tilted so that the hydrochloric acid makes contact with the floor. A pressure compensation was attained by sinking the container so that, after about 10 minutes the gas volume can be read. Color was determine by assembling Filter apparatus (membrane filter, filter holder, aspirator and folter flask) and allowed about $50 \mathrm{ml}$ of dematerialized water to pass through to rinse the unit. Discard rinse water. Approximately $50 \mathrm{ml}$ of water sample was filtered and $25 \mathrm{ml}$ poured into another clean cell. The dematerialized water was placed in a cell holder and sample compartment door was closed. The demineralization was used to set the zero concentration point.

To assess the levels of the heavy metals, running water (2.0 litre) from the three sites of the river were collected from plastic containers that have been evacuated and fully sterilized. A portion of the water sample $(50 \mathrm{ml})$ were fixed using concentrated nitric acid and hydrochloric acid in a ratio of 1: 10 respectively, which was meant to digest particulate matter inside the sample by heating in a water bath to obtain thick yellow solution, and later was cooled and made up to $100 \mathrm{ml}$ with distilled water. The samples were then directly analyzed to within $\pm 1.0 \mathrm{~nm}$ accuracy using the Bulk Scientific Atomic Absorption Spectrophotometer (AAS). For each heavy metal, specific concentration standard was run, to prepare a calibration curve from which the concentration of the heavy metal was read directly from the AAS VDU system.

\section{Results}

\subsection{Environmental parameters}

All environmental parameters, except pH, Cadmium (Cd), Chromium (Cr) Ammonium (NH4+), Lead ( $\mathrm{Pb}$ ), alkalinity, Surface Temperature, Air temperature, water velocity and rainfall, showed significant variation between sampling sites $(\mathrm{p}<0.05)$ (Table 1). Highest values of water discharge $(1496.5 \pm 82.9)$, dissolved oxygen

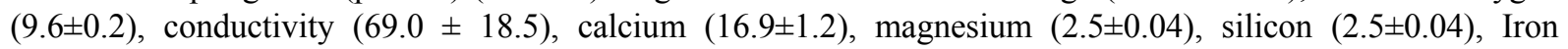
$(0.08 \pm 0.02)$, Manganese $(0.8 \pm 0.2)$, Total solids $(178.6 \pm 8.8)$ and Total hardness (74.5 \pm 4.3$)$ were recorded in waterfalls region (midstream) of the river while water level $(4.8 \pm 0.6 \mathrm{~m})$, size $(160.4 \pm 9.2)$, depth $(68.9 \pm 2.9)$, transparency (28.8 \pm 3.4 ), Biochemical oxygen demand (BOD) (4.8 \pm 1.2 ), Phosphates (2.9 \pm 0.2 ), sulfates (19.8 \pm 7.7$)$, Nitrates $(0.8 \pm 0.6)$, Chlorides $(15.4 \pm 4.2)$ and Total dissolved solids (88.4 \pm 4.2$)$ were highest downriver. Most parameters, except, BOD, Phosphates, sulfates and chlorides were lowest upstream.

The data showed that rain fell in most months (May- January) during the period of study, and that water level was positively correlated with rainfall intensity. Due to variation in flood regime caused by dry and wet season, water level and water depth fluctuate and the values of Secchi disc transparency were inversely proportional to water level (Wl), water depth (Wd), water velocity (Wv), water discharged (Wdi) and conductivity (CD) (Figure 2). Wet month values of Wl $(7.6 \mathrm{~m}), \mathrm{Wd}(9.8 \mathrm{~m}), \mathrm{Wv}(1.8 \mathrm{~m} / \mathrm{s}), \mathrm{Wdi}\left(845 \mathrm{~m}^{3} / \mathrm{s}\right)$ and $\mathrm{CD}(136.4 \mu \mathrm{S} / \mathrm{cm})$ were higher than dry season values $(7.5 \mathrm{~m}, 1.5 \mathrm{~m}, 0.6 \mathrm{~m} / \mathrm{s}, 248.8 \mathrm{~m} 3 / \mathrm{s}$ and $34.5 \mu \mathrm{S} / \mathrm{cm}$, respectively) while dry season transparency was higher $(0.5 \mathrm{~m})$ than wet $(0.1 \mathrm{~m})$. Also, some chemical properties like TS, TDS, TH, DO, $\mathrm{Sio}_{4}$, $\mathrm{PO}_{4}, \mathrm{Cl}$, and $\mathrm{So}_{4}$ showed higher values during the wet months, while others like $\mathrm{NH}_{3}$ and BOD were higher during dry (Figure 3).

Among the heavy metals, only Copper $(\mathrm{Cu})$ showed higher upstream values, others were concentrated midstream (waterfall region). Also, all heavy metals except Magnesium $(\mathrm{Mg})$, Copper $(\mathrm{Cu})$ and Calcium $(\mathrm{Ca})$ recorded higher concentrations during the wet months of September and October (Figure 4).

\section{Discussion}

Physico-chemical parameters recorded in this study serve as indication of the level of water quality of the different sections of the Agbokum waterfall during different seasons. Positive correlation between water level and rainfall indicate that the water level increases with increasing rainfall. Variation in amount and duration of 
rainfall had been found (Egborge, 1994) to affect physico-chemical parameters of water (Adebisi, 1981). Inverse relationship between transparency and other hydrological parameters agrees with findings by Egborge (1977) in inland waters. They both established that as flooding occurred due to heavy rainfall and consequent rise in water levels, water width, water velocity, water depth and water discharge, run-off from nutrient rich agricultural lands and other industries increased, particles and debris are carried along while others are re-suspended under action of wind. The resultant high rate of turbidity affects the water transparency and consequent increase in the nutrient concentration. The higher concentration of some parameters in this study may be due to the road construction carried out near the study area as large amount of silt and rock salt (applied to road) generated, are washed into the river. The high level of some parameters during wet season is due to rain water carrying wastewater from various sources. Dissolved oxygen level $(9.7 \mathrm{mg} / \mathrm{l})$ recorded in the waterfall region of the study area was higher compared to other parts of the river and higher than $4.94-5.9 \mathrm{mg} / 1$ recorded for Ogun river (Adebisi, 1981) and 2.4-7.0 mg/l for Calabar River (Asuquo, 1999) both in Nigeria. Low organic enrichment and turbulence nature of waterfall had been suggested (Mason (1992) as the possible reason responsible for such high oxygen values. On the other hand, low dissolved oxygen observed downstream of the waterfalls could be attributed to low water velocity thus reducing the movement of the waters (Odinetz, 1989) and dissolution of oxygen. Oxidation of humic compounds available for decomposition as a result of inundation of lands, numerous swamps and forest in this region (Enrique, 1992) could bring down oxygen in the area. Also photosynthetic activity is reduced due to forest cover along the shoreline, hence reduction in dissolved oxygen (Silva \& Rowland, 1987). The values of dissolved oxygen fell within the ranges (5.0- $9.0 \mathrm{mg} / \mathrm{l})$ documented by Alabaster (1982) for good water quality suitable for aquatic organisms. Seasonal variation in dissolved oxygen content with higher values during the rains could be due to lower water temperature and increased aeration due to increased agitation of the water. BOD values were less than $5 \mathrm{mg} / \mathrm{l}$ in all site and seasons sampled, indicating absence of organic matter pollution sources in the area (Patki, 2002). Average $\mathrm{pH}$ values obtained in this study agree with those documented by Fakayode (2005) as values most suitable for maximum productivity of aquatic organisms. Though normal biological activity is restricted to $\mathrm{pH}$ of 6-8, for natural water, the EEC (1980) guide limit for water requiring simple physical treatment and disinfection is $6.5-8.5$. Our water samples from the three sampling sections of the river and the two seasons in the study area, recorded $\mathrm{pH}$ values within $5.8-7.4$. Low wet season $\mathrm{pH}$ values indicate that the water resource is not suitable for fish culture and drinking during the period, and might be due to higher input of allochthonous organic matter and increased anthropogenic acidification from rain water and runoff from neighboring farmlands. The dry season $\mathrm{pH}$ levels in this study indicate moderate quality of water. None of the samples used for determining TDS was up to maximum admissible concentration $(600 \mathrm{mg} / \mathrm{l})$ of total solids as stipulated by WHO (1989) and EEC (1976). The guide limit (EEC, 1976) of water conductivity is $400 \mu \mathrm{S} / \mathrm{cm}$. From our data, only the wet season samples were up to $146 \mu \mathrm{S} / \mathrm{cm}$. The Mean value, $22.6 \mathrm{mg} / 1$ of chloride concentration, recorded in the waterfalls region and $76.4 \pm 2.2$ $\mathrm{mg} / \mathrm{l}$ downstream, were lower than the value $(105.8 \pm 7.8 \mathrm{mg} / \mathrm{l})$ from Cross River (Offem et al., 2009) but higher than $15.6 \pm 3.7 \mathrm{mg} / \mathrm{l}$ from Obubra lake (Offem et al., 2011) in Nigeria and Kheenjhar Lake (88.8 \pm 3.2 in Pakistan (Goel et al., 1980). Higher level of chlorides downstream is an indication that either the seawater within the area has great influence in the waterfalls or due to organic pollution by domestic sewage (NEERI, 1979; Goel et al., 1980). Alkalinity in the waterfalls during this study was found to be within tolerance limit of biota indicating good water quality. However, $38.2 \pm 3.4 \mathrm{mg} / \mathrm{l}$ recorded was comparable to $48.9 \mathrm{mg} / \mathrm{l}$ in Ejagham lake (Offem et al., 2011) but lower than $288.8 \pm 20.1 \mathrm{mg} / \mathrm{l}$ from Cross River (Offem et al., 2009) and $287 \mathrm{mg} / \mathrm{l}$ in Keenjhar lake (Korai, 2008). Total hardness $88.8 \mathrm{mg} / \mathrm{l}$ in waterfalls was far less than, values from Cross River $(208 \pm 10.6 \mathrm{mg} / 1$ (Offem et al., 2009), $143 \pm 23.2 \mathrm{mg} / 1$ Ejagham lake and 370mg/l Keenjhar lake. The value relates to moderately soft water according to DWAF (1996), classification of water in terms of hardness and softness: 0-50 (soft), 50-100 (moderately soft), 100-150 (moderately hard), and 250 and above (hard). Higher values in the waterfall region may be as a result of rocky substratum and higher wet season hardness could be due to inputs from runoff. Sulfate concentration was low in all study sites and seasons probably due to low-level combustion of Sulphur containing hydrocarbon fuels in the area. This observation is supported by low levels of acidity in the area. Level of nitrate concentration is far lower than the Target Water Quality Range (TWQR) for nitrates indicating good water quality. Therefore, biological oxidation of nitrogenous organic matter of both autochthonous and allochthonous origin (e.g. domestic sewage, agricultural runoffs and effluents from industries), the major source of aquatic nitrates, are at their minimum in the study area (Saxena, 1998). Nitrates are required by all organisms for the basic process of life to make proteins required for growth and reproduction.

The higher levels in the waterfalls region of all heavy metals investigated but Copper, $(\mathrm{Cu})$ might be due to the turbulence nature of this section of the river which brings up heavy metal lost to the sediments. Higher level concentration of heavy metals in wet season samples may also be due to effluents from runoff and 
water-sediment mixing process which is at maximum due to wind and storm during this season. We have reasons to be very concerned because although WHO (1998) recommended $0.1 \mathrm{mg} / \mathrm{l}$ for $\mathrm{Pb}$ and $0.003 \mathrm{mg} / \mathrm{l}$ for $\mathrm{Cd}$, all waterfall and wet season samples where these metals were detected, in this study, quite exceeded the limit and therefore were potentially toxic. Results have shown that concentrations of Lead $(\mathrm{Pb})$ in excess of $0.19 \mathrm{mgl}{ }^{-\mathrm{L}}$ and $0.30 \mathrm{mgL}^{-1}$ can be potentially harmful to Daphnia magna and Cyclop spp respectively (Offem et al., 2008). Cadmium high content may be due to prevailing logging activities along the shoreline of the waterfalls and other areas since trace metals such as Cadmium is known to be found in woody and herbaceous materials (Clarke \& Sloss, 1992). Cadmium has long biological life of about 20-30 years. Chronic exposures may eventually accumulate to levels toxic even to man (Hodgson \& Levi, 1987). The WHO (1998) recommended limit for $\mathrm{Cr}$ is $0.05 \mathrm{mg} / \mathrm{l}$. Our dry season sample of $0.02 \pm 0.01 \mathrm{mg} / \mathrm{l}$ and waterfalls samples of $0.04 \mathrm{mg} / \mathrm{l}$ falls below the limit. Chromium ( $\mathrm{Cr}$ ) is an essential trace nutrients and is a vital component for glucose tolerance, though, Chromium toxicity damages the liver and kidney (WHO 1988). For Cu, the recommended level in water is $20 \mathrm{mg} / \mathrm{l}$ (Pearson, 1976) and values of $\mathrm{Cu}$ detected in this study were far below the recommended limit. Iron is an essential metal but frequent acute and chronic Fe overload may results in renal failure (Muller Eberhard et al., 1977). Our data show very unacceptable Fe levels of $0.8 \mathrm{mg} / \mathrm{l}$ in wet season samples and $0.08 \mathrm{mg} / \mathrm{l}$ in waterfalls samples which may constitute bad water quality and a risk to health, considering the WHO standard of $0.01 \mathrm{mg} / \mathrm{l}$. The high concentration of iron for dry and wet seasons is expected because it has been reported that iron occurs at high levels in Nigerian soils (Prater et al., 1977). A water treatment softener plan can help with the problem. Zinc is an essential trace metal and all the samples contain appreciable concentrations. WHO action level for Zinc is $3 \mathrm{mg} / \mathrm{l}$ which is below the concentrations of wet season and waterfall samples in this study. However, $\mathrm{Zn}$ does not accumulate with continuous exposure and body content is modulated by homeostatic mechanism that acts mainly on liver levels (Walshe et al., 1995). Manganese is an essential element and co-factor for several enzymatic reactions. WHO (1984) action level for Manganese is $0.1 \mathrm{mg} / 1$. Therefore, results from waterfall and wet season samples showed major threats from Mn poisoning. Mena et al. (1967) reported incidence of respiratory diseases in victims of $\mathrm{Mn}$ poisoning. The level of magnesium was quite low in all sites but values were higher during the dry months than wet caused by leaching of rocks in the catchment. It is an important component in the exoskeleton of arthropods and shells of mollusk (Piska, 2000).

The general outlook of the entire result, indicating higher concentrations of most physic-chemical parameters in the waterfalls section of the river during the wet season may be explained as resulting from high flushing rate in the waterfalls during wet season. The influx of the river water has sufficient energy to cause turbulent water movements which could result in flushing of the water body including sediment. Natural run-off subsurface is also involved in contributing to the concentration level of some heavy metals during the wet season. On the other hand, in the dry season, sedimentation would become more efficient since the water environment is only distributed by wind effect (Asaolu et al., 1997).

\section{Conclusion}

Deleterious levels of $\mathrm{Fe}, \mathrm{Pb}, \mathrm{Cd}$ and $\mathrm{Mn}$, above recommended levels, in the waterfalls region of the river during the wet season, coupled with the acidic nature of the wet samples poses potential health hazards to the aquatic organisms and the inhabitants of the area that use this water resource directly for domestic purpose without treatment. The results indicate a deteriorating water quality of Agbokum waterfalls with the waterfalls region and wet season samples being most critical in any effort geared towards ensuring effective water resource management.

\section{References}

Adebisi, A. A. (1981). The physico-chemical hydrology of tropical seasonal rivers, Upper Ogun River. Hydrobiologia, 75(2), 254-262.

Akpan, E. R., \& Offem, J. O. (1993). Seasonal variation in water quality of the Cross River State, Nigeri. Revue Hydrobiologue Tropicale, 26(2), 95-103.

Alabaster, J. S. (1982). Report of the EIFAC workshop on fish-farm effluents. Tech. Pap. 41 FAO. Rome. pp 11-83.

Ama-Abasi, D., Akpan, E. R., \& Holzlohner, S. (2004). Factors influencing the emigration of juvenile bonga from the Cross River Estuary. Proceedings of the Annual Conference of the Fisheries Society of Nigeria (FISON), Ilorin, Kwara State, Nigeria, pp737-744.

APHA (American Public Health Association). (1998). Standard methods for the examination of water and waste water $20^{\text {th }}$ Edition. American Public Health Association Inc. New York, USA. 
APHA, A. D. Eaton. (2005). American Public Health Association, Mary Ann H. Franson, American Water Works Association(Ed.), Standard Methods for the Examination of Water \& Wastewater.

Asaolu, S. S., Ipinmoroti, K. O., Adeyinwo, C. E., \& Olaofe, O. (1997). Seasonal Variation in Heavy Metal Distribution in Sediment of Ondo State Coastal Region. Ghana Journal of Chemistry. 3(1), 11-16.

Asuquo FE, 1999. Physico-chemical characteristics and anthropogenic pothition of the surface waters Calabar River, Nigeria. Global Journal of Pure and Applied science, 5(4), 595-600.

Ayodele, I. A. (1988). An ecological basis for the management of Old Oyo Natrional Park. Ph.D Thesis, Department of Wildlife and Fisheries Management, University of Ibadan. 220pp.

Ayodele, I. A., \& Ajani, E. K. (1999). Essentials of fish farming (Aquaculture). Odufuwa Press, Ibadan. 48pp.

Balogun, J. K. \& Aduku, U. J. (2004). Predicting the fisheries potentials of inland reserviors and lakes: A Case study of Kubanni Reservior, Ahmadu Bello University, Zaria (Chapter 6).

Boyd, C. E., \& Lichtkpoppler, F. R. (1985). Water quality management in pond fish culture. Auburn University Auburn, Alabama (Chapter 3).

Chapman, D. W. (1996). The Texas Basins Project. Transactions of American Fisheries Society. 45(4), 27-30.

Chernicoff, S., Fox, H., \& Venkatakrishnan, R. (1997). Essentials of Geology. Worth Publishers, New York, Chapter 8.

Chester, T., Strong, J., \& Ayers, P. (1999). SGM: The Waterfalls. Assessed from http://tchester.org/sgm/lists/waterfalls.html

Chowdhury S.H., \& Mazumder A. (1981). Limnology of the Lake Kaptai-1. Physico-chemical features. Bangladish Journal of Zoology, 9(2), 59-67.

Daddy, F., \& Falaye, A. E. (2004). Potentials for sustainable flood plain fisheries development: A case study of Tatabu Flood Plain, Fisheries Society of Nigeria (Chapter 4).

European Economic Community (EEC). (1976). EC Standards for surface waters used for portable. EEC, Brussels. (Chapter 5).

European Economic Community (EEC). (1980). EC Drinking Water Standards. Directive 80/778/EEC. EEC Brussels(Chapter 2).

Efe, S. T. (2002a). Urban warming in Nigerian cities. The case of Warri metropolis. African Journal of Environmental Studies. 2(2), 6.

Efe, S. T. (2002b). An appraisal of the quality of rain and Ground Water Resources in Nigerian cities. The case of Warri Metropolis. PhD Thesis Delta State University, Nigerian, 1-19pp.

Egborge A.B.M. (1977). The hydrology and Plankton of Asejire Lake. University of Ibadan, publishers, Nigeria (Chapter 7).

Egborge A.B. (1994). Biodiversity and chemistry of Warri River. Ben Miller. Warri, Nigeria (Chapter 3).

Etim, L., \& Akpan, E. R. (1997). Seasonal variation of metal (Hg, Ph, As) in the body tissue of Egeria radiata (Lamark) from Cross River, Nigeria. Journal of African Zoology, 105, 465-472.

Enrique V. (1992). Temperature and dissolved oxygen in Lake of the Lower River Floodplain (Venezuela) Hydrobiologia 25, 23-33.

Fakayode S.O. (2005). Impact assessment of industrial effluents on water quality of the receiving Alaro river Ibadan Nigeria. Ajean Ragee (Chapter 1).

Fischer, G., \& Harris, M. (2003). Waterfalls of Ontario. Waterfallogy 101. Retrieved from http://www.startica/user/mharris/waterfallogy.htm (January 17, 2006).

Krinitskii, L. (1972). Protected Areas in the worlds industrially advanced regions: importance, progress and problems. Proceedings Second World Conference on National Parks (Chapter 5).

Goel P.K., Gopal B., \& Trivedy. (1980). Impact of sewage on Freshwater ecosystem. General features of water bodies and sewage. Journal of Ecology and Environmental Science, 12, 45-78

Golterman, H. I. (1969). Method of chemical analysis of freshwater. Int. Biol. Program. Handbook, Oxford, Blackwell scientific Publications (Chapter 5). 
Islam A.K.M.N., Haroon A.K.Y., \& Zaman K.M. (1974). Limnological studies of River Buriganga. Dhaka University Stud (Chapter 6).

Mason, C. F. (1992). Biology of fresh water pollution. Weley and sons, New York (Chapter 6).

Mbagwu, I. G. (1991). Preliminary survey of macrobenthos of Tiga Lake, Kano State, Nigeria. Unpublished M.Sc Thesis Bayero University Kano (Chapter 3).

Mena I., Meurin O., Feunzobda S., \& Cotzias G.C. (1967). Chronic Manganese poisoning. Clinical picture and Manganese turnover. Neurology 17, 128-134.

Muller-Eberhand U., Miescher P.A., \& Jaffe E.R. (1977). Iron Excess. Aberrations of Iron andPorphyrin metabolism. Grun and Stratton, NewYork (Chapter 9).

Offem, B. O., Samsons, Y. A., Omonyi, I. T., \& Ikpi, G. U. (2009). Dynamics of the limnological features and diversity of zooplankton populations of the Cross Rvier System, South East Nigeria. Knowledge and Management. of Aquatic Ecosystems, 02, 1-19.

Offem B. O., Ayotunde E.O., Ikpi G.U., Ochang S.N., \& Ada F.B. (2011). Effect of seasons on water quality and biodiversity of ikwori lake, south-eastern nigeria Journal of Envromental Protection, 2, 305-323.

Patki Saroj F. (2002). Hydrobiological studies of Banshelki dam at Ugdi. PhD Thesis Marawathda University.

Pearson D. (1976). The chemical analysis of foods. Churchill-Livingstone, Edinburg (Chapter 6).

Rahim, K. A. A., Long, S. M., \& Abang, F. (2002). A survey of freshwater fish fauna in the upper rivers of Crocker Range National Park Sabah, Malaysia. ASEAN Review of Biodiversity and Environment Conservation, $8,1-9$.

Saxena S. (1998). Settling studies on pulp and paper mill wastewater. Indian Journal of Environmental Health, 20, 273-279

Walshe C.T., Sandstead H.H., \& Prasad A.S. (1995). Zinc: Health effects and research priorities for the environment. Health perspects. 102, 5-46

World Health Organization. (1984). WHO Guidelines for Drinking Water Quality WHO, Geneva (Chapter 5). 
Table 1. Mean ( $\pm \mathrm{SD}$ ) values of some physical and chemical characteristics of the three regions (upstream, waterfalls and downstream) of the river.

\begin{tabular}{|c|c|c|c|}
\hline Parameters & Upstream & Waterfalls & Downstream \\
\hline Rainfall (mm) & $238.8-48.0^{\mathrm{a}}$ & $238.8-48.0^{\mathrm{a}}$ & $238.8-48.0^{\mathrm{a}}$ \\
\hline Water level (m) & $2.4 \pm 0.7^{\mathrm{a}}$ & $3.6 \pm 0.5^{\mathrm{b}}$ & $4.8 \pm 0.6^{\mathrm{c}}$ \\
\hline Water velocity $\left(\mathrm{ms}^{-1}\right.$ & $0.94 \pm 0.25^{\mathrm{a}}$ & $1.01 \pm 0.26^{\mathrm{a}}$ & $1.27 \pm 0.32^{\mathrm{a}}$ \\
\hline Water discharged $\left(\mathrm{m}^{3} \mathrm{~s}^{-1}\right)$ & $156.71 \pm 124.25^{\mathrm{a}}$ & $1496.46 \pm 825.98^{b}$ & $189.84 \pm 133.82^{\mathrm{c}}$ \\
\hline Water width (m) & $12.07 \pm 8.76^{\mathrm{a}}$ & $15.8 \pm 6.44^{\mathrm{b}}$ & $26.4 \pm 9.22^{\mathrm{c}}$ \\
\hline Mean Depth (m) & $3.44 \pm 1.81^{\mathrm{a}}$ & $4.6 \pm 2.26^{b}$ & $8.4 \pm 2.45^{\mathrm{c}}$ \\
\hline Air Temperature $\left({ }^{\circ} \mathrm{C}\right)$ & $30.9 \pm 2.23^{\mathrm{a}}$ & $32.5 \pm 1.84^{\mathrm{a}}$ & $34.4 \pm 3.42^{b}$ \\
\hline Surface Temperature $\left({ }^{\circ} \mathrm{C}\right)$ & $26.0 \pm 1.1^{\mathrm{a}}$ & $26.6 \pm 1.2^{\mathrm{a}}$ & $27.2 \pm 0.8^{\mathrm{a}}$ \\
\hline Transparency $(\mathrm{cm})$ & $26.6 \pm 13.9^{\mathrm{a}}$ & $20.5 \pm 14-4^{b}$ & $28.8 \pm 13.4^{\mathrm{c}}$ \\
\hline $\mathrm{pH}$ & $7.0 \pm 0.2^{\mathrm{a}}$ & $7.2 \pm 1.12^{\mathrm{a}}$ & $7.3 \pm 0.3^{\mathrm{a}}$ \\
\hline Dissolved Oxygen $\left(\mathrm{mg} . \mathrm{l}^{-1}\right)$ & $2.8 \pm 0.3^{\mathrm{a}}$ & $9.61 \pm 0.2^{\mathrm{b}}$ & $5.6 \pm 0.5^{\mathrm{c}}$ \\
\hline Alkalinity (mg. $\left.1^{-1}\right)$ & $38.2 \pm 6.11^{\mathrm{a}}$ & $41.2 \pm 4.33^{\mathrm{a}}$ & $36.89 \pm 5.12^{\mathrm{a}}$ \\
\hline Conductivity $\left(\mu \mathrm{S} . \mathrm{cm}^{-1}\right)$ & $36.6 \pm 11.0^{\mathrm{a}}$ & $69.1 \pm 18.5^{\mathrm{b}}$ & $38.8 \pm 09.78^{\mathrm{c}}$ \\
\hline $\mathrm{BOD}\left(\mathrm{mg} . \mathrm{l}^{-1}\right)$ & $2.6 \pm 1.43^{\mathrm{a}}$ & $1.7 \pm 0.87^{b}$ & $4.8 \pm 1.21^{\mathrm{c}}$ \\
\hline Phosphates (mg/l) & $1.5 \pm 0.51^{\mathrm{a}}$ & $0.5 \pm 0.04^{b}$ & $2.9 \pm 0.23^{c}$ \\
\hline Calcium $\left(\mathrm{Ca}^{++}\right)$ & $6.4 \pm 2.4^{\mathrm{a}}$ & $16.9 \pm 1.23^{\mathrm{b}}$ & $8.5 \pm 5.34^{c}$ \\
\hline Magnesium $\left(\mathrm{Mg}^{++}\right)$ & $0.8 \pm 0.22^{\mathrm{a}}$ & $2.5 \pm 0.54^{\mathrm{b}}$ & $1.2 \pm 0.99^{c}$ \\
\hline Total hardness $(\mathrm{mg} / \mathrm{l})$ & $179.9 \pm 34.7^{\mathrm{a}}$ & $178.9 \pm 34.7^{\mathrm{a}}$ & $189.9 \pm 34.7^{\mathrm{a}}$ \\
\hline Silicon $\left(\mathrm{SiO}_{2}\right)$ & $13.4 \pm 3.65^{\mathrm{a}}$ & $38.4 \pm 5.34^{\mathrm{b}}$ & $21.8 \pm 2.34^{\mathrm{c}}$ \\
\hline Lead $(\mathrm{Pb}) \mathrm{mg} / \mathrm{l}$ & $0.15 \pm 0.1^{\mathrm{a}}$ & $0.27 \pm 0.02^{\mathrm{a}}$ & $0.17 \pm 0.06^{\mathrm{a}}$ \\
\hline $\mathrm{NH}_{4}(\mathrm{mg} / \mathrm{l})$ & $0.02 \pm 0.1^{\mathrm{a}}$ & $0.01 \pm 0.1^{\mathrm{a}}$ & $0.02 \pm 0.01^{\mathrm{a}}$ \\
\hline Chronium (Cr)mg/1 & $0.01 \pm 0.1^{\mathrm{a}}$ & $0.02 \pm 0.01^{\mathrm{a}}$ & $0.01 \pm 0.01^{\mathrm{a}}$ \\
\hline Cadmium(Cd)mg/1 & $0.02 \pm 0.01^{\mathrm{a}}$ & $0.06 \pm 0.01^{\mathrm{a}}$ & $0.02 \pm 0.01^{\mathrm{a}}$ \\
\hline $\operatorname{Iron}(\mathrm{Fe}) \mathrm{mg} / \mathrm{l}$ & $0.5 \pm 0.1^{\mathrm{a}}$ & $0.08 \pm 0 . .2^{b}$ & $0.04 \pm 0.02^{\mathrm{c}}$ \\
\hline Copper $(\mathrm{Cu}) \mathrm{mg} /$ & $0.08 \pm 0.01^{\mathrm{a}}$ & $0.01 \pm 0.01^{\mathrm{a}}$ & $0.01 \pm 0.01^{\mathrm{a}}$ \\
\hline Zinc $(\mathrm{Zn}) \mathrm{mg} / \mathrm{l}$ & $1.9 \pm 1.2^{\mathrm{a}}$ & $3.8 \pm 0.8^{b}$ & $2.6 \pm 0.2^{\mathrm{c}}$ \\
\hline Manganese(Mn)mg/l & $0.2 \pm 0.1^{\mathrm{a}}$ & $0.8 \pm 0.2^{\mathrm{b}}$ & $0.4 \pm 0.2^{\mathrm{c}}$ \\
\hline Sulphates $\left(\mathrm{SO}_{4}^{-}{ }^{-}\right)$ & $11.4 \pm 1.23^{\mathrm{a}}$ & $6.8 \pm 2.88^{b}$ & $19.8 \pm 7.81^{\mathrm{c}}$ \\
\hline Nitrates $\left(\mathrm{NO}_{3}^{-}\right)$ & $0.2 \pm 0.78^{\mathrm{a}}$ & $0.4 \pm 0.34^{\mathrm{b}}$ & $0.8 \pm 0.56^{\mathrm{c}}$ \\
\hline Chlorides $\left(\mathrm{Cl}^{-}\right)$ & $49.6 \pm 2.34^{\mathrm{a}}$ & $22.6 \pm 1.37^{\mathrm{b}}$ & $76.4 \pm 2.23^{\mathrm{c}}$ \\
\hline Total hardness & $27.5 \pm 8.88^{\mathrm{a}}$ & $74.5 \pm 4.34^{\mathrm{b}}$ & $45.5 \pm 13.65^{\mathrm{c}}$ \\
\hline Total solids (mg/l) & $18.9 \pm 12.34^{\mathrm{a}}$ & $178.6 \pm 8.76^{\mathrm{b}}$ & $88.3 \pm 54.50^{\mathrm{c}}$ \\
\hline Total Dissolved solids (mg/l) & $59.8 \pm 6.54^{\mathrm{a}}$ & $38.4 \pm 4.21^{\mathrm{b}}$ & $88.6 \pm 8.77^{\mathrm{c}}$ \\
\hline
\end{tabular}

Values in the same rows with the same superscript are not significantly different $(\mathrm{p}>0.05)$ 


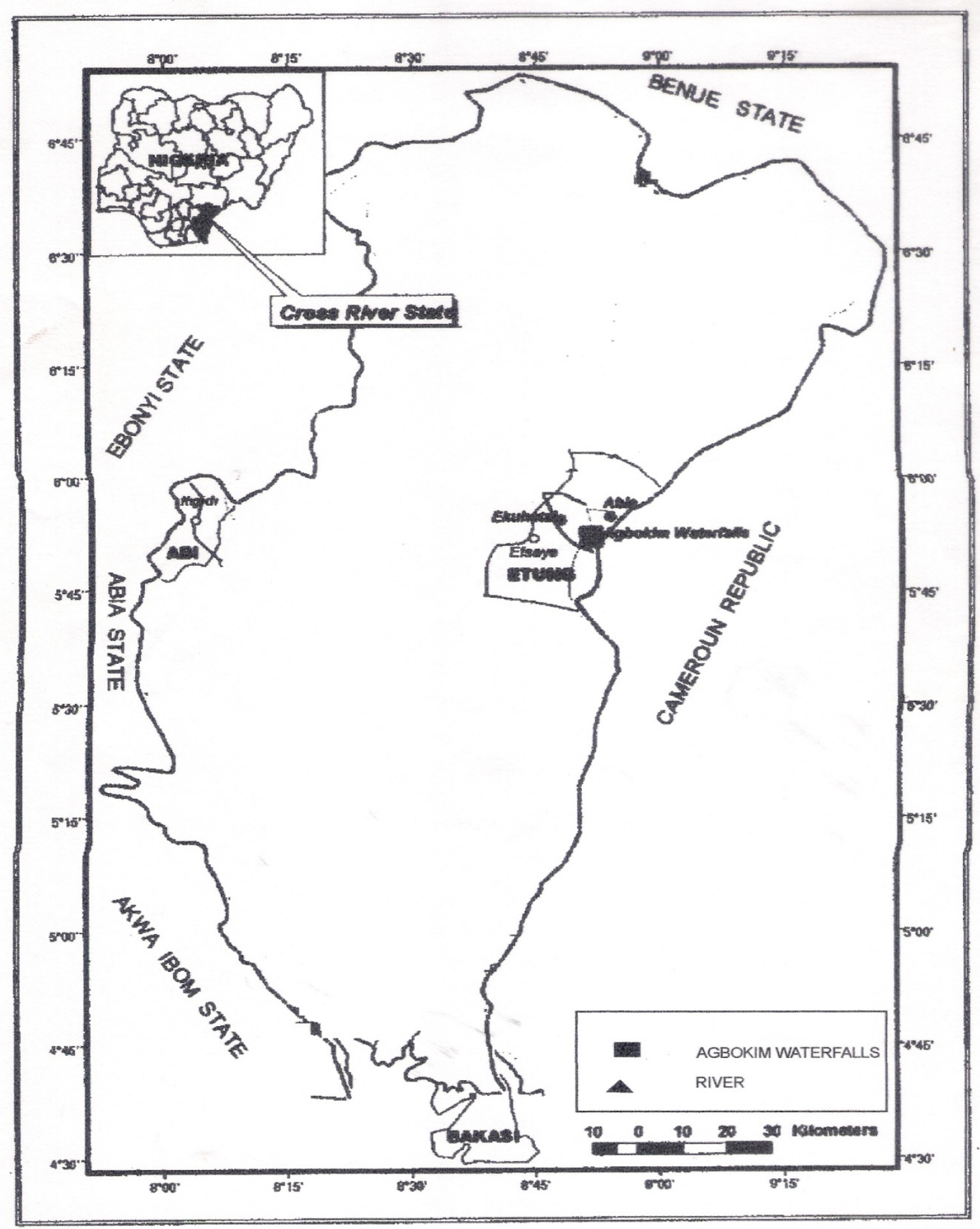

Figure 1. Map of Cross River State showing study area 


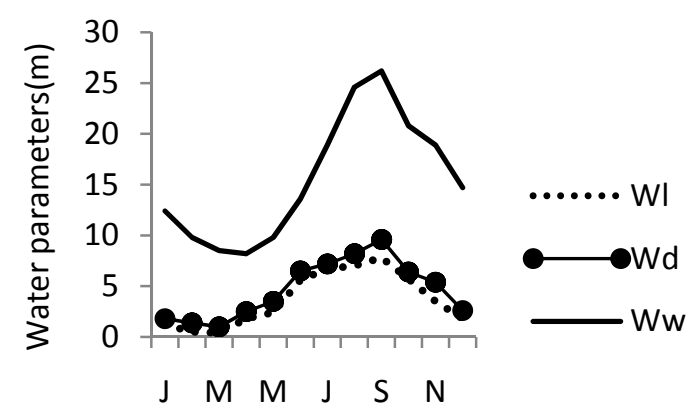

Months(2005-2009)

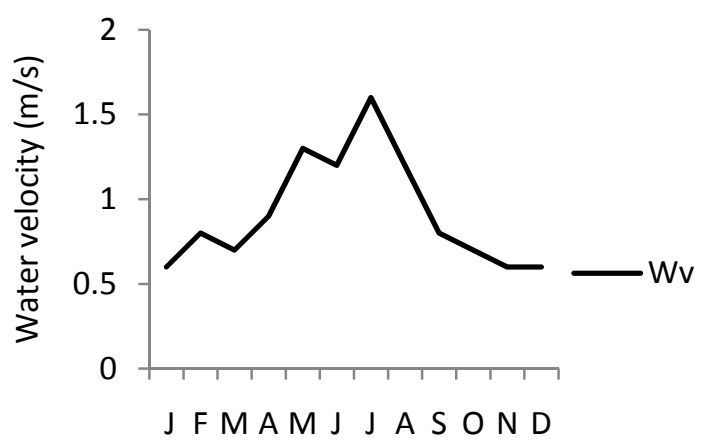

Months (2007-2009)

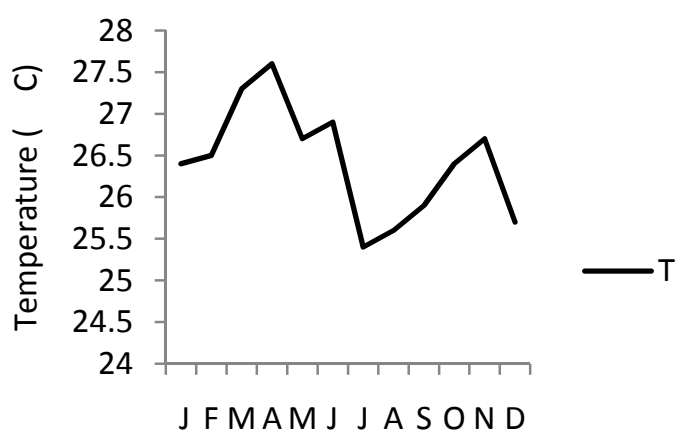

Months (2007-2009)

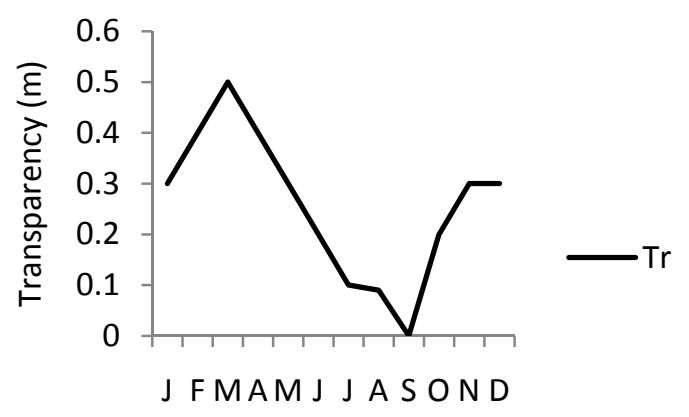

Months(2007-2009
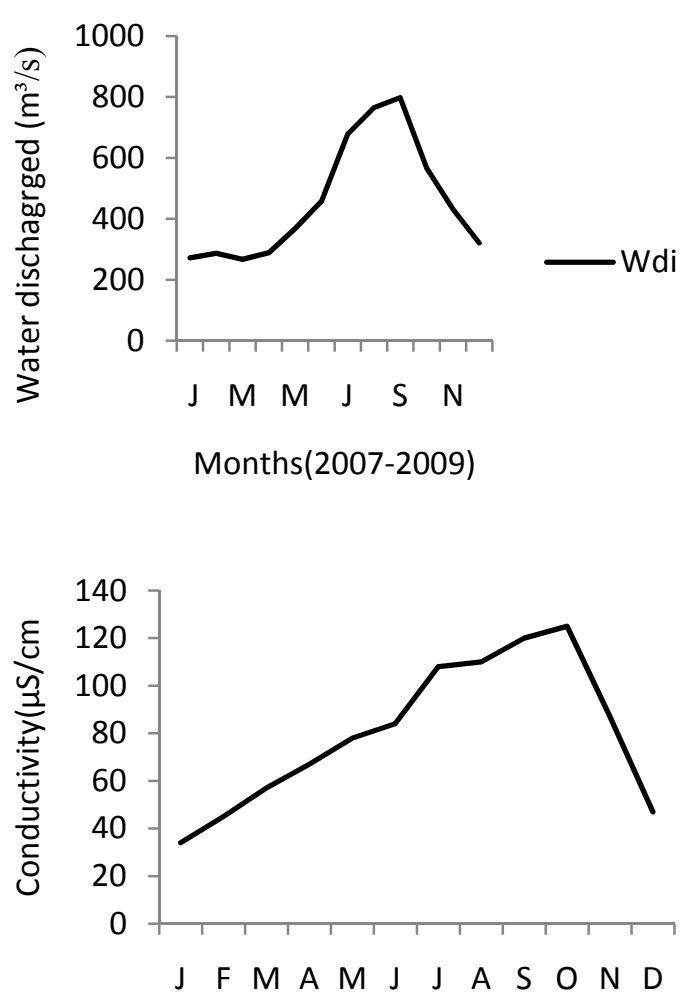

Months( 2007-2009

Figure 2. Seasonal variation in the hydrological parameters of Agbokum waterfalls 

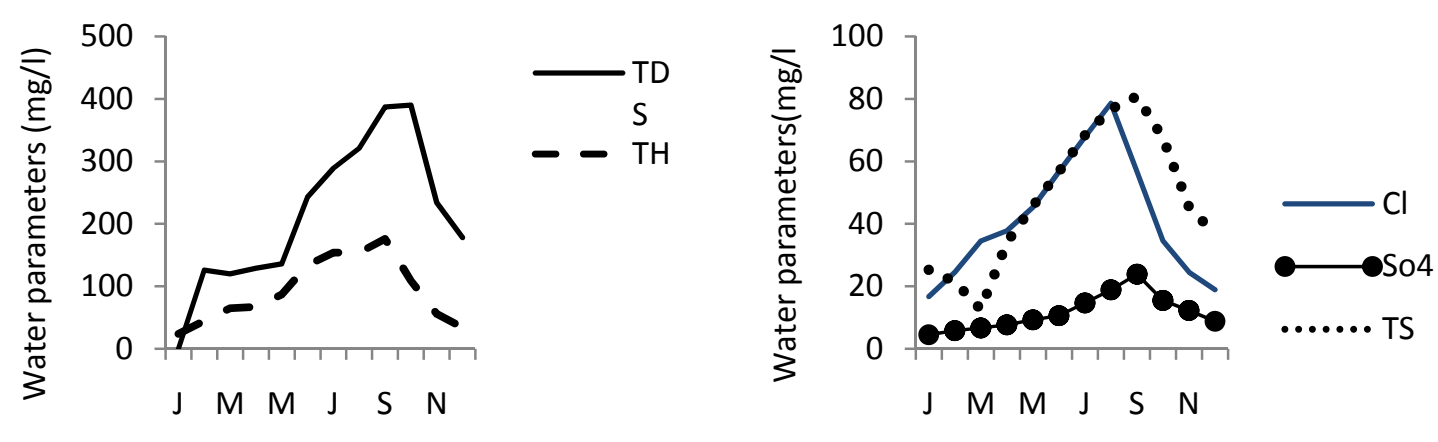

Months (2007-2009)

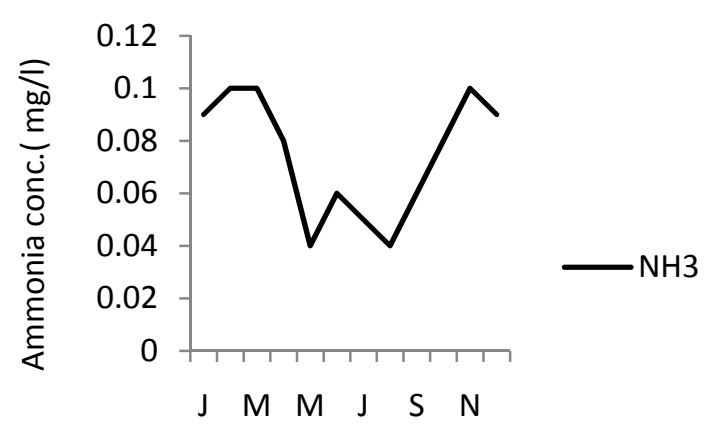

Months(2007-2009)
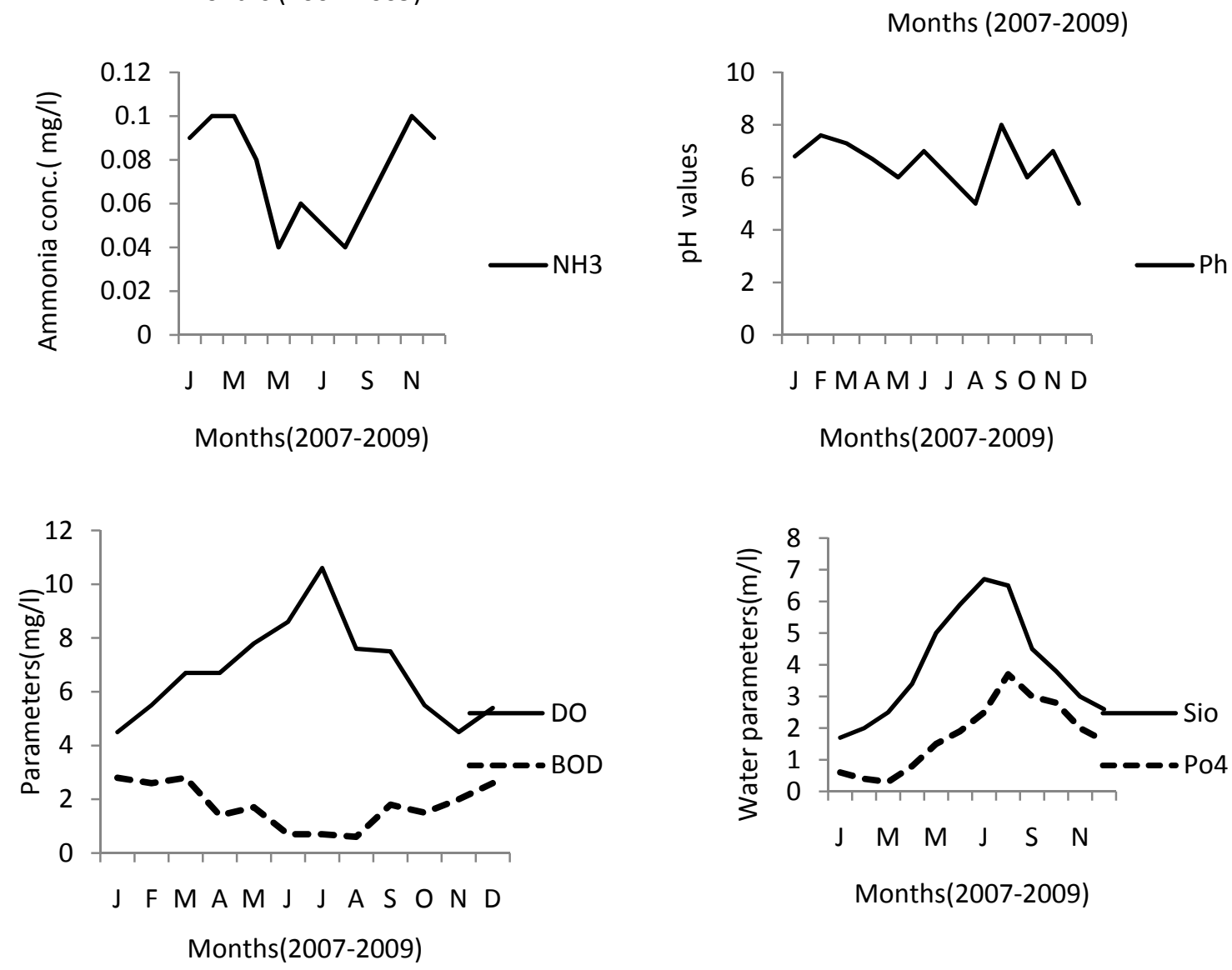

Figure 3. Seasonal variation in the chemical parameters of Agbokum waterfalls 


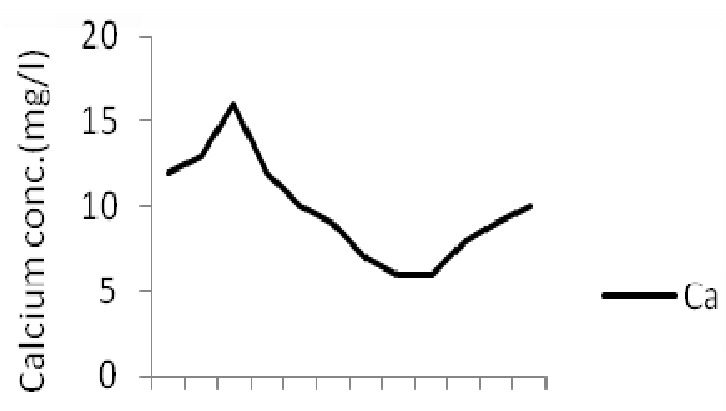

J FMAMJ JASOND

Months(2007-2009)

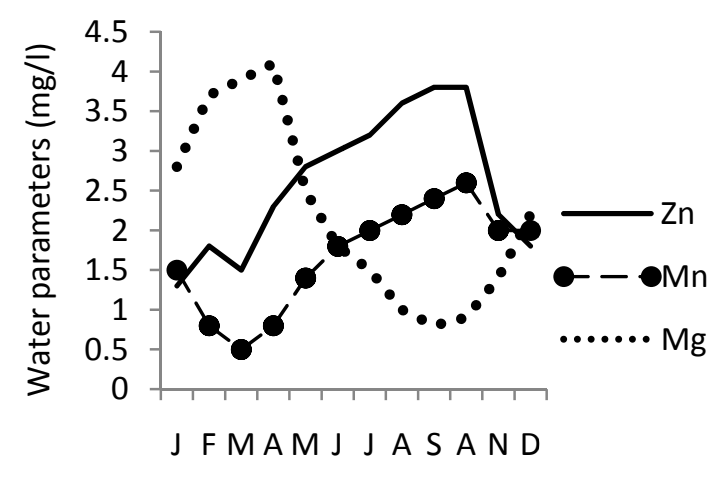

Months(2007-2009)

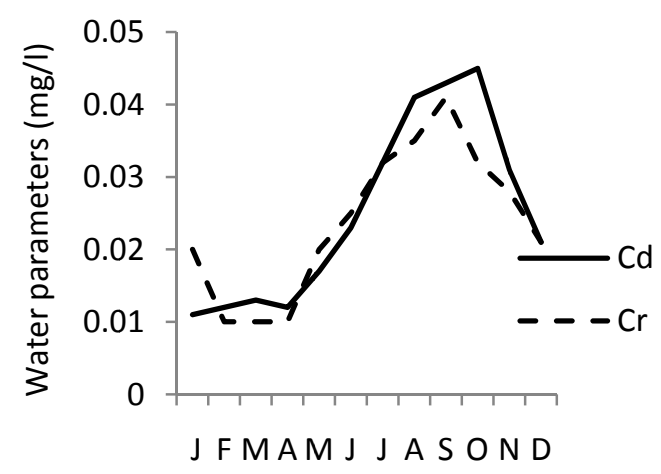

Months(2007-2009)

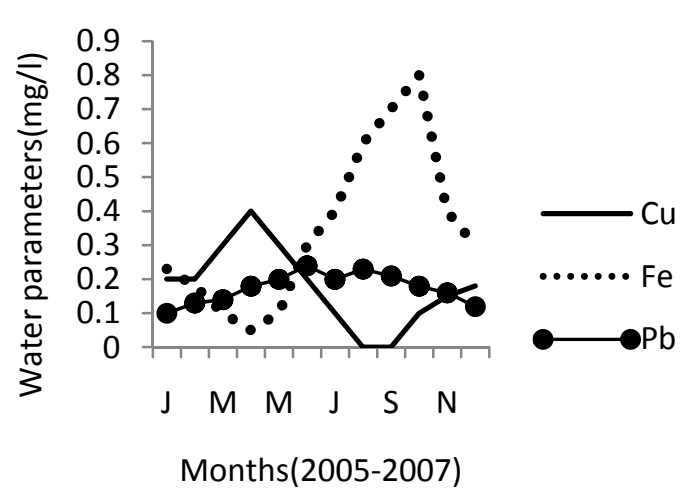

Figure 4. Seasonal variation in the concentrations of heavy metals 